\title{
Hormographiella aspergillata: an emerging basidiomycete in the clinical setting? A case report and literature review
}

\author{
Maxime Moniot ${ }^{1,2^{*}}$ (D), Rose-Anne Lavergne ${ }^{3}$, Thomas Morel ${ }^{1}$, Romain Guieze ${ }^{4}$, Florent Morio ${ }^{3}$, \\ Philippe Poirier ${ }^{1,2}$ and Céline Nourrisson ${ }^{1,2}$
}

\begin{abstract}
Background: Filamentous basidiomycetes are mainly considered to be respiratory tract colonizers but the clinical significance of their isolation in a specimen is debatable. Hormographiella aspergillata was first reported as a human pathogen in 1971. We discuss the role of this mold as a pathogen or colonizer and give an update on diagnostic tools and in vitro antifungal susceptibility.

Case presentation: We identified three cases of $\mathrm{H}$. aspergillata with respiratory symptoms in a short period of time. One invasive infection and two colonizations were diagnosed. Culture supernatants showed that $\mathrm{H}$. aspergillata can produce galactomannan and $\beta$-D-glucan but not glucuronoxylomannan. For the first time, isavuconazole susceptibility was determined and high minimum inhibitory concentrations (MICs) were found. Liposomal amphotericin B and voriconazole have the lowest MICs.

Conclusion: To date, 22 invasive infections involving $\mathrm{H}$. aspergillata have been reported. On isolation of $\mathrm{H}$. aspergillata, its pathogenic potential in clinical settings can be tricky. Molecular identification and antifungal susceptibility testing are essential considering high resistance against several antifungal therapies.
\end{abstract}

Keywords: Hormographiella aspergillata, Coprinus cinereus, Mould, Antifungal susceptibility, Fungal colonization, Basidiomycete

\section{Background}

Filamentous basidiomycetes are mainly considered to be respiratory tract colonizers but increasingly these molds are being documented in invasive infections [1]. Hence, the clinical significance of their isolation in a specimen is debatable. Hormographiella aspergillata is a filamentous basidiomycete growing on horse dung. It was found in

\footnotetext{
* Correspondence: mmoniot@chu-clermontferrand.fr

'Laboratoire de Parasitologie-Mycologie, CHU Clermont-Ferrand, CHU Gabriel Montpied, 58 rue Montalembert, 3lHP, 63003 Clermont-Ferrand Cedex 1, France

${ }^{2}$ Equipe Interactions Hôte-Parasite, Laboratoire Microorganismes : Génome et Environnement, CNRS, Université Clermont-Auvergne, Clermont-Ferrand, France

Full list of author information is available at the end of the article
}

numerous environmental substrates and first reported as a human pathogen in 1971 [2-4]. Since, a few infections were reported all over the world with various clinical outcomes, essentially pulmonary but also disseminated or located to the eye or the skin [2,5-22]. Thus, data are sparse for the diagnosis and management of such infections. Here, we report a new case of human infection involving $H$. aspergillata and two cases of colonization. We then review all previously published cases and discuss diagnostic strategy and clinical management.

\section{Case presentation}

The first case (HA1) was an 70-year-old man admitted to the hematology department for prolonged febrile

(c) The Author(s). 2020 Open Access This article is licensed under a Creative Commons Attribution 4.0 International License, which permits use, sharing, adaptation, distribution and reproduction in any medium or format, as long as you give appropriate credit to the original author(s) and the source, provide a link to the Creative Commons licence, and indicate if changes were made. The images or other third party material in this article are included in the article's Creative Commons licence, unless indicated otherwise in a credit line to the material. If material is not included in the article's Creative Commons licence and your intended use is not permitted by statutory regulation or exceeds the permitted use, you will need to obtain permission directly from the copyright holder. To view a copy of this licence, visit http://creativecommons.org/licenses/by/4.0/ The Creative Commons Public Domain Dedication waiver (http://creativecommons.org/publicdomain/zero/1.0/) applies to the data made available in this article, unless otherwise stated in a credit line to the data. 
neutropenia and anorexia. He had a history of acute myeloid leukemia (AML) and hematopoietic stem cell transplantation (HSCT). His C-reactive protein (CRP, positivity threshold value: $3 \mathrm{mg} / \mathrm{L}$ ) was $135 \mathrm{mg} / \mathrm{L}$ and empirical antibiotic therapy (ceftriaxone) was started at day 210 (D210, 7th month) post-HSCT. Chest computed tomography (CT) scan showed right lower lobe opacification (Fig. 1a) that had increased 1 week later (Fig. 1b). Invasive fungal infection (IFI) was suspected, and liposomal amphotericin B (lAmB $5 \mathrm{mg} / \mathrm{kg} /$ day) was started on D232 (7th month). Microscopic examination of a bronchoalveolar lavage (BAL) sampled at D237 (7th month) showed septate hyphae (Fig. 2) but cultures on Sabouraud media incubated at $25^{\circ} \mathrm{C}$ and $35^{\circ} \mathrm{C}$ were sterile after 7 days. $H$. aspergillata was identified by sequencing the internal transcribed spacer (ITS) region of fungi directly from the BAL. Interestingly, serum galactomannan monitoring was negative $\left(<0.1\right.$ on repeated samples; Platelia ${ }^{\circ}$ Aspergillus assay, Bio-Rad; positivity threshold index: $>0.5)$ and $\beta$-Dglucan (Fungitell ${ }^{\circ}$, Cape Cod; positivity threshold value: $80 \mathrm{pg} / \mathrm{mL}$ ) was weakly positive on D237 (7th month; 98 $\mathrm{pg} / \mathrm{mL}$ ) but negative on D248 (8th month; $46 \mathrm{pg} / \mathrm{mL}$ ). In accordance with the 2008 European Organization for Research and Treatment of Cancer/Invasive Fungal Infections Cooperative Group and the National Institute of Allergy and Infectious Diseases Mycoses Study Group (EORTC/MSG) criteria, the patient was classified as having probable IFI [23]. His condition worsened following pulmonary Stenotrophomonas maltophilia infection and so it was decided to initiate palliative care. $\mathrm{AmB}$ was stopped on D253 (8th month), 3 weeks after its introduction. The patient died on D298 (9th month).

The second patient (HA2) was a 49-year-old man admitted to the intensive care unit for pneumopathy with acute respiratory failure. He had a history of psychiatric disorders, diabetes mellitus, asthma, smoking and middle cerebral artery stroke with persistent sequelae. CRP was negative on admission. The following day, it was positive at $108.0 \mathrm{mg} / \mathrm{L}$ but procalcitonin remained negative. Mechanical ventilation and empirical antibiotic therapy

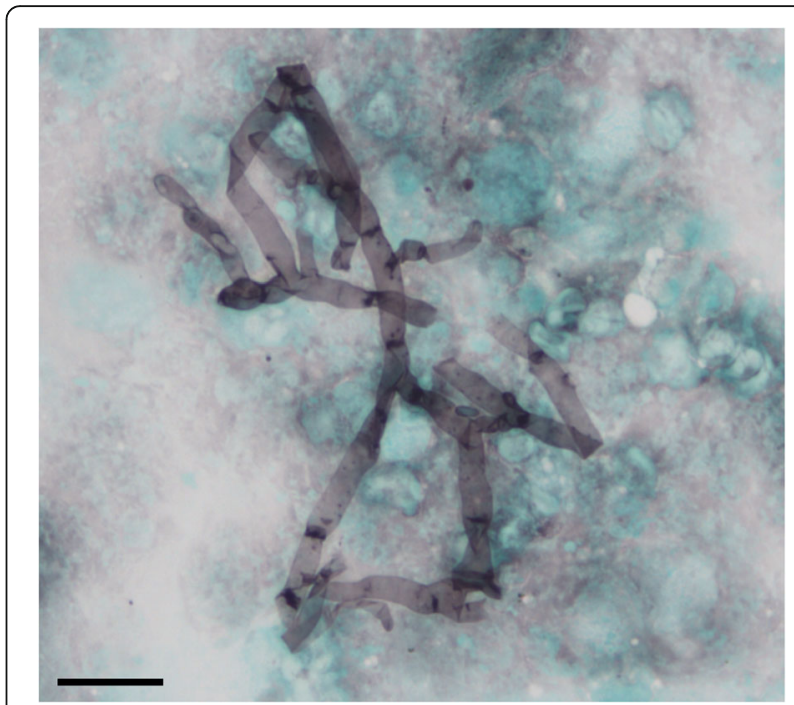

Fig. 2 Microscopy examination of bronchoalveolar lavage from patient HA1 by Gomori-Grocott staining showing the presence of septate hyphae. Scale-bar: $10 \mu \mathrm{m}$

(ceftazidime) were initiated. A mucous plug containing purulent secretions in the left lung was removed by fibroscopy and transmitted to Bacteriology and Mycology Laboratories. Microscopy examinations of samples were negative but cultures identified oropharyngeal microbiota associated with a white mold on Sabouraud media at $25^{\circ} \mathrm{C}$ and $35^{\circ} \mathrm{C}$ after 7 days. Subcultures of mold grew with white to slightly cream-colored velvety colonies (Fig. 3a and b) on potato dextrose agar media. Microscopy examination of cultures showed hyaline septate hyphae with conidiophores producing cylindrical arthroconidia (Fig. 3c and d). H. aspergillata identification was confirmed by sequencing the ITS region. In vitro antifungal susceptibility testing was performed via broth microdilution technique according to the European Committee on Antimicrobial Susceptibility Testing (EUCAST) guidelines [24]. Minimum inhibitory concentrations (MICs) are given in Table 1 . The chest CT scan was unremarkable and there was no risk factor for IFI and so no antifungal

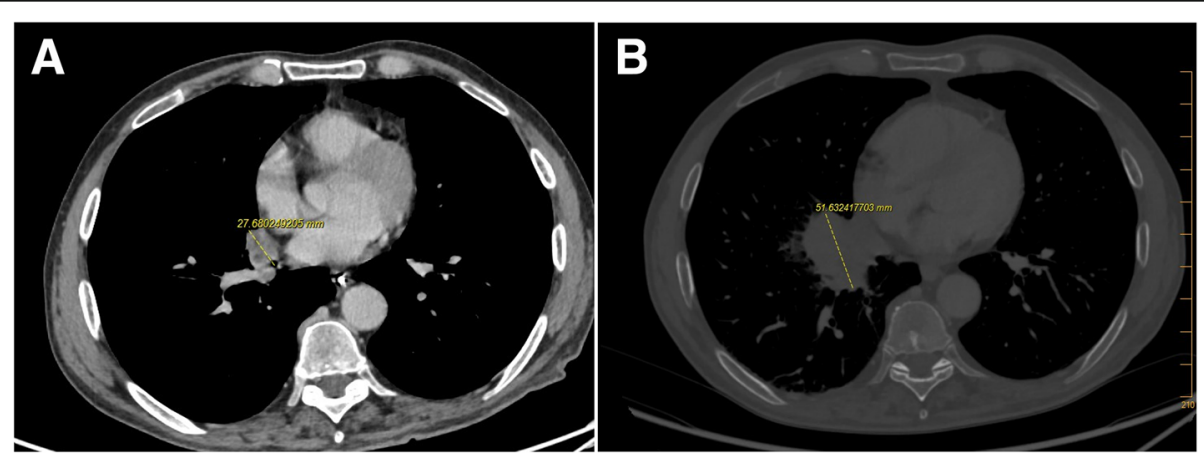

Fig. 1 Chest computed tomography scan of HA1 patient showing a right lower lobe opacification and $\mathbf{b}$ increase in the lesion size 1 week later 
therapy was initiated. The inflammatory syndrome decreased rapidly 3 days later, and the patient's condition improved. A putative diagnosis of bacterial aspiration pneumonia with fungal colonization was established.

The third patient (HA3) was a 28-year-old woman admitted for investigation of an inflammatory disease affecting the central nervous system treated by methylprednisolone for 3 days $(1 \mathrm{~g} /$ day). Bronchial fibroscopy was performed along with other investigations. Initial microscopy examination of the sample was negative but $H$. aspergillata grew after 3 weeks on Lowenstein-Jensen medium at $35^{\circ} \mathrm{C}$ because of mycobacterial suspicion (identification confirmed by ITS sequencing). Antifungal susceptibility testing was performed as described above (Table 1). The patient was asymptomatic and her chest CT scan normal, suggesting colonization, and so no antifungal treatment was initiated.

\section{Literature review}

We reviewed the literature since 1971 to date using the terms "Hormographiella aspergillata" or "Coprinus cinereus" and "infection" in MEDLINE database (Tables 1 and 2). For each strain, antifungals MIC with the method used were reported in Table 1 when available. According to the 2008 EORTC/MSG criteria, all probable or proven IFI due to $H$. aspergillata were reported in Table 2 with significant clinical details.

\section{Discussion and conclusions}

Hormographiella aspergillata is an environmental filamentous basidiomycete found in numerous substrates including soils, leaves, pressmud compost and in the air [3, 4]. It is the anamorph form of Coprinopsis cinerea (formerly Coprinus cinereus), which commonly grows on horse dung. It can be an opportunistic pathogen and is the second filamentous basidiomycete responsible for human infection after Schizophyllum commune [25]. To date, 22 invasive infections involving $H$. aspergillata have been reported (Table 2), mostly identified by sequencing of the $28 \mathrm{~S} \mathrm{rDNA}$ or ITS regions [2, 5-22]. Most cases were diagnosed in Europe, but some were documented in the United States, Japan and India, in both rural and urban areas [2, 5-22]. Infection cases occurred mainly in neutropenic patients. Although $H$. aspergillata is primarily responsible for pulmonary

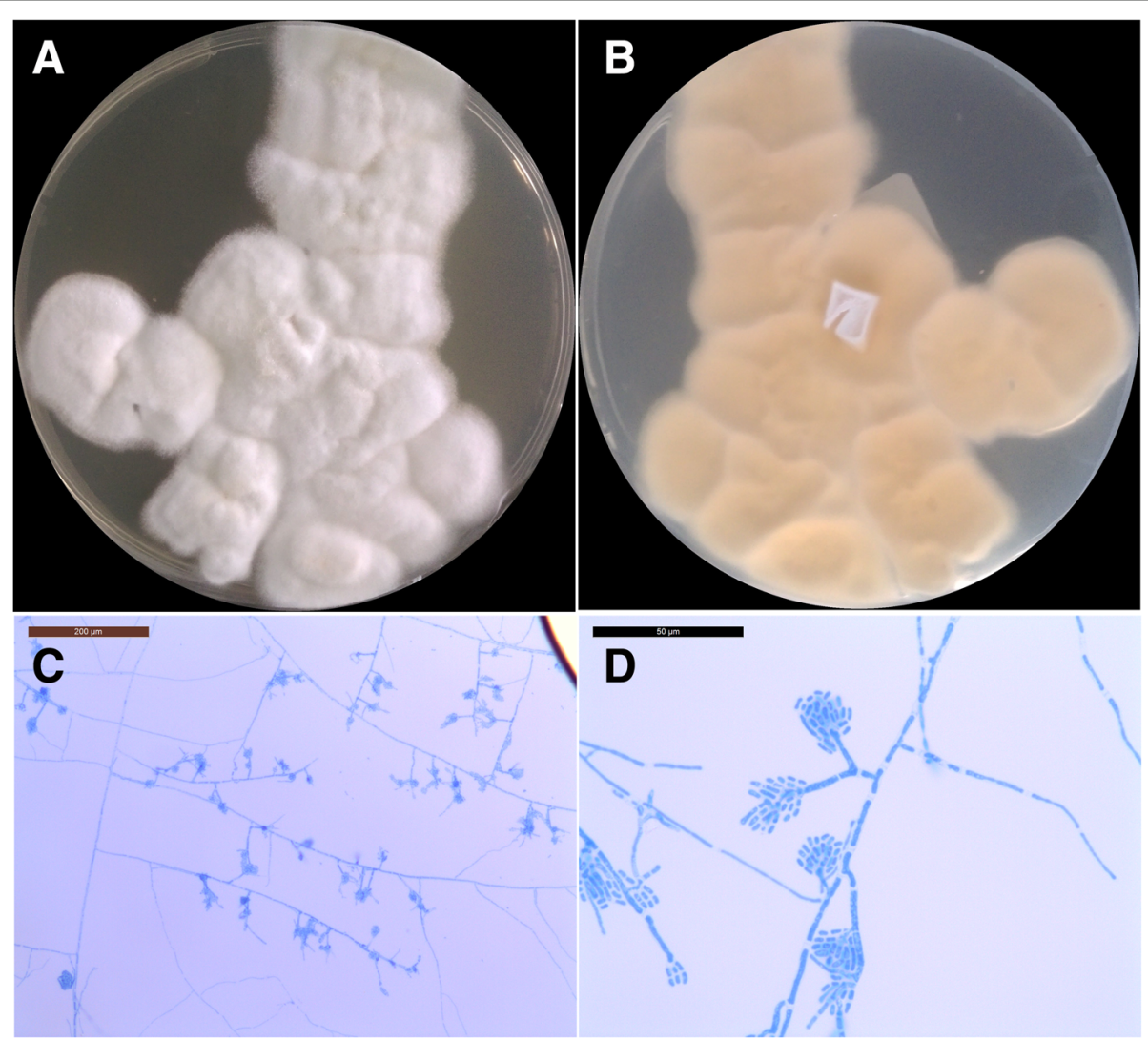

Fig. 3 Macroscopic and microscopic morphology of Hormographiella aspergillata on potato dextrose agar (PDA) subculture after 3 days of incubation at $25^{\circ} \mathrm{C}$. a White to cream colored velvety colonies with irregular margin on the recto side. $\mathbf{b}$ Verso side of the colonies showing light yellow color. c, d Slide culture of Hormographiella aspergillata showing hyaline septate hyphae with conidiophores and cylindrical arthroconidia without clamp connection, scale-bar: $200 \mu \mathrm{m}$ (c) and $50 \mu \mathrm{m}$ (d) 
Table 1 Antifungal susceptibility testing of Hormographiella aspergillata from the literature and our cases

\begin{tabular}{|c|c|c|c|c|c|c|c|c|c|c|c|}
\hline \multirow[b]{2}{*}{ References } & \multirow[b]{2}{*}{ Year } & \multirow[b]{2}{*}{ Method } & \multicolumn{9}{|c|}{ MIC (mg/L) for single isolates } \\
\hline & & & $\mathrm{AmB}$ & $5-\mathrm{FC}$ & $\mathrm{FCZ}$ & ITZ & VRZ & PSZ & ISA & CSF & MCF \\
\hline Speller and Maclver [2]. & 1971 & Dilution method on Yeast Morphology Agar & 0.25 & $>250$ & l & l & I & I & I & l & I \\
\hline Verweij et al. [6] & 1997 & Broth macrodilution method with RPMI-1640 & 0.5 & l & $>64$ & 8 & I & I & l & l & l \\
\hline Lagrou et al. [8] & 2005 & E-test ${ }^{\oplus}$ & 0.5 & l & l & 2 & 0.25 & l & l & l & l \\
\hline Abuali et al. [10] & 2009 & Broth microdilution method according to CLSI M38-A2 & 4 & l & l & l & 0.25 & 0.5 & l & $>2$ & $>4$ \\
\hline Conen et al. [11] & 2011 & E-test ${ }^{\oplus}$ & 0.5 & l & 256 & / & 0.125 & I & l & 32 & / \\
\hline Conen et al. [11] & 2011 & E-test ${ }^{\oplus}$ & 0.5 & I & l & l & 0.125 & 2 & l & I & l \\
\hline Conen et al. [11] & 2011 & E-test ${ }^{\oplus}$ & 0.5 & / & $>256$ & / & 0.25 & I & l & $>32$ & / \\
\hline Suarez et al. [12] & 2011 & Broth microdilution method according to EUCAST & 2 & $>64$ & 64 & $>8$ & 1 & I & l & 2 & / \\
\hline Bojic et al. [14] & 2013 & E-test ${ }^{\oplus}$ & 0.094 & $>32$ & $>256$ & / & 0.125 & 0.064 & l & l & / \\
\hline Nanno et al. [17] & 2016 & Not available & 0.125 & $>64$ & 4 & 0.25 & 0.015 & / & l & I & $>16$ \\
\hline Koncan et al. [18] & 2016 & Sensititre YeastOne & 0.12 & / & 16 & / & 0.03 & 0.125 & I & l & / \\
\hline Jain et al. [21] & 2019 & Not available & 0.3 & I & I & 4 & 0.5 & I & l & 4 & 4 \\
\hline $\begin{array}{l}\text { Our report } \\
\text { HA2 }\end{array}$ & 2019 & Broth microdilution method according to EUCAST & 0.125 & l & I & $>8$ & 2 & 4 & 4 & I & l \\
\hline $\begin{array}{l}\text { Our report } \\
\text { HA3 }\end{array}$ & 2019 & Broth microdilution method according to EUCAST & 0.125 & I & I & $>8$ & 8 & $>8$ & 16 & I & I \\
\hline
\end{tabular}

${ }^{*} A M B$ Amphotericin B, 5-FC Flucytosine, FCZ Fluconazole, ITZ Itraconazole, VRZ Voriconazole, PSZ Posaconazole, ISA Isavuconazole. CSF Caspofungin, MCF Micafungin

infections it can occasionally cause primary cutaneous lesions $[10,14,19]$. H. aspergillata is able to grow in blood cultures [11] and a few cases of disseminated infections have been reported, affecting the small intestine, the eye and the brain $[11,16,17,22]$. Interestingly, three cases of IFI have also been reported in immunocompetent patients following cardiac or ophthalmic surgery $[2,9,21]$. The most contributive samples were biopsies, but some cases were diagnosed with BAL. $[8,15] \mathrm{H}$. aspergillata grows well on different fungal media without cycloheximide at $25^{\circ} \mathrm{C}$ or $35^{\circ} \mathrm{C}$. However, diagnosis can be challenging in patients with negative cultures, as for the HA1 patient, whose strain was probably inhibited by the concomitant antifungal treatment. To date, there are insufficient data to draw any conclusions about biomarkers since in all documented reports galactomannan assays were negative and only two observations reported strongly positive $\beta$-D-glucan antigens greater than $500 \mathrm{pg} / \mathrm{mL}[18,22]$. We attempted to evaluate the production of galactomannan, $\beta$-D-glucan and glucuronoxylomannan antigens on in vitro cultures. Glucuronoxylomannan is a capsular antigen of Cryptococcus neoformans widely used to diagnose cryptococcosis. Some cross-reactions have already been described with other basidiomycete pathogens such as Trichosporon sp. or even Coprinopsis cinerea [26]. Interestingly, culture supernatants from strains HA2 and HA3 showed that $H$. aspergillata can produce galactomannan and $\beta$-D-glucan but not glucuronoxylomannan (Table 3). Although, as for HA1, results in sera are variable, biomarker assays could provide supplementary evidence in patients with suspected IFI.
$H$. aspergillata can also be a colonizer of the respiratory tract, as illustrated in our three patients, all of whom had an underlying respiratory condition. The weak clinical significance of the isolation of basidiomycetes in healthy subjects, in contrast with their lifethreatening potential in immunocompromised patients, has already been described with Schizophyllum commune or Ceriporia lacerata, for example [27, 28]. These fungi are widely present in the environment, and their spores are easily inhaled and can grow in pulmonary alveoli in cases of local or systemic impaired function of alveolar macrophages.

As yet there are no EUCAST nor Clinical and Laboratory Standards Institute (CLSI) breakpoints to interpret the antifungal MICs for $H$. aspergillata. However, previous articles have reported in vitro resistance to echinocandins, fluconazole along with high MIC for flucytosine (Table 1). We found higher MICs for isavuconazole ( 4 and $16 \mathrm{mg} / \mathrm{L}$ ) than what is usually observed for basidiomycetes [28, 29]. In the light of our findings and data from the literature, $1 \mathrm{AmB}$ and voriconazole have the lowest MICs. However, $H$. aspergillata infections have a poor prognosis even when surgical debridement is performed.

In conclusion, on isolation of $H$. aspergillata, its pathogenic potential in clinical samples should be interpreted together with the patient's history. Formal identification of the fungus can be tricky and usually requires molecular tools in addition to culture. Basidiomycetes can also be contaminants or colonizers and so microscopy examination of samples and/or histology in 
Table 2 Literature review of Hormographiella aspergillata infections in humans published since 1971

\begin{tabular}{|c|c|c|c|c|c|c|c|c|c|c|}
\hline \multirow{2}{*}{$\begin{array}{l}\text { References } \\
\text { Speller and Maclver [2]. }\end{array}$} & \multirow{2}{*}{$\begin{array}{l}\text { Country } \\
\text { England }\end{array}$} & \multirow{2}{*}{$\begin{array}{l}\text { Year } \\
1971\end{array}$} & \multirow{2}{*}{$\begin{array}{l}\text { Infection } \\
\text { site } \\
\text { Heart }\end{array}$} & \multirow{2}{*}{$\begin{array}{l}\text { EORTC/MSG } \\
\text { classification } \\
\text { Proven }\end{array}$} & \multirow{2}{*}{$\begin{array}{l}\begin{array}{l}\text { Underlying } \\
\text { disease }\end{array} \\
\text { Prosthetic Valve }\end{array}$} & \multicolumn{2}{|c|}{$\begin{array}{l}\text { Diagnosis } \\
\text { Samples - Methods }\end{array}$} & \multirow{2}{*}{$\begin{array}{l}\begin{array}{l}\text { Antifungal } \\
\text { treatment }\end{array} \\
\text { None }\end{array}$} & \multirow{2}{*}{$\begin{array}{l}\text { Surgery } \\
\text { Yes }\end{array}$} & \multirow{2}{*}{$\begin{array}{l}\text { Outcome } \\
\text { Died }\end{array}$} \\
\hline & & & & & & Autopsy & Histology + culture & & & \\
\hline Nenoff et al. [5] & Germany & 1997 & Lung & Proven & ALL & Autopsy & Histology + culture & $A m B$ & No & Died \\
\hline Verweij et al. [6] & Netherlands & 1997 & Lung & Proven & ALL & Autopsy & $\begin{array}{l}\text { Histology + culture } \\
+ \text { RFLP }\end{array}$ & $\mathrm{AmB} \rightarrow \mathrm{ITZ}$ & No & Died \\
\hline Surmont et al. [7] & Belgium & 2002 & Lung & Proven & Lymphoma & $\begin{array}{l}\text { Transthoracic } \\
\text { puncture }\end{array}$ & $\mathrm{DE}+$ culture & $A m B$ & No & Alive \\
\hline Lagrou et al. [8] & Belgium & 2005 & Lung & Probable & AML & BAL & $\mathrm{DE}+$ culture & CSF & No & Died \\
\hline Greer et al. [9] & USA & 2008 & Heart & Proven & Valve prosthesis & $\begin{array}{l}\text { Resected } \\
\text { valve }\end{array}$ & Histology + culture & IAmB & Yes & Alive \\
\hline Abuali et al. [10] & USA & 2009 & Skin & Proven & AML & Skin biopsy & Culture & $\begin{array}{l}\mathrm{VRZ} \rightarrow \mathrm{PSZ}+ \\
\mathrm{CSF} \rightarrow \mathrm{IAmB}+ \\
\mathrm{CSF}\end{array}$ & No & Died \\
\hline \multirow[t]{3}{*}{ Conen et al. [11] } & Switzerland & 2011 & $\begin{array}{l}\text { Lung, } \\
\text { eye, CNS, } \\
\text { blood }\end{array}$ & Proven & $\mathrm{AML}$ & Autopsy & Histology + culture & $\begin{array}{l}\mathrm{VRZ} \rightarrow \mathrm{PSZ} \rightarrow \\
\mathrm{CSF}\end{array}$ & No & Died \\
\hline & & & Lung & Proven & $\mathrm{AML}$ & Lung biopsy & Histology + culture & $\begin{array}{l}\mathrm{VRZ} \rightarrow \mathrm{PSZ} \rightarrow \\
\mathrm{IAmB} \rightarrow \mathrm{VRZ}\end{array}$ & Yes & Died \\
\hline & & & Lung & Proven & AML & Lung biopsy & Histology + culture & $\begin{array}{l}\mathrm{VRZ} \rightarrow \mathrm{IAmB} \\
\rightarrow \mathrm{VRZ}\end{array}$ & Yes & Died \\
\hline \multirow[t]{2}{*}{ Suarez et al. [12] } & France & 2011 & Lung & Proven & BAL & Lung biopsy & $\mathrm{DE}+$ culture & $\begin{array}{l}\mathrm{CSF} \rightarrow \mathrm{VRZ} \rightarrow \\
\mathrm{IAmB}\end{array}$ & No & Alive \\
\hline & & & Lung & Proven & X-ALD & Autopsy & $\begin{array}{l}\text { Histology + culture } \\
+ \text { PF-PCR }\end{array}$ & $\mathrm{CSF} \rightarrow \mathrm{Am} B$ & No & Died \\
\hline Pang et al. [13] & France & 2012 & Lung & Proven & ALL & Lung biopsy & Culture & $\begin{array}{l}\mathrm{CSF} \rightarrow \mathrm{VRZ} \rightarrow \\
\mathrm{IAmB}\end{array}$ & No & Alive \\
\hline Bojic et al. [14] & Austria & 2013 & $\begin{array}{l}\text { Skin, } \\
\text { lung }\end{array}$ & Proven & AML & Skin biopsy & Histology & $\begin{array}{l}\mathrm{CSF} \rightarrow \mathrm{IAmB}+ \\
\mathrm{VRZ}\end{array}$ & Yes & Died \\
\hline Corzo-León et al. [15] & USA & 2015 & Lung & Probable & $\mathrm{AML}$ & BAL & Culture & $\mathrm{VRZ} \rightarrow \mathrm{A} \mathrm{AmB}$ & No & Died \\
\hline Heiblig et al. [16] & France & 2015 & $\begin{array}{l}\text { Sinus, } \\
\text { orbit, } \\
\text { CNS }\end{array}$ & Proven & $\mathrm{AML}$ & Sinus biopsy & $\mathrm{DE}+$ culture & $\begin{array}{l}\mathrm{CSF} \rightarrow \mathrm{PSZ} \rightarrow \\
\mathrm{IAmB}+\mathrm{VRZ}\end{array}$ & Yes & Died \\
\hline Nanno et al. [17] & Japan & 2016 & $\begin{array}{l}\text { Lung, } \\
\text { CNS, } \\
\text { small } \\
\text { intestine }\end{array}$ & Proven & MDS & Lung biopsy & $\begin{array}{l}\text { Histology + culture } \\
+\beta D G\end{array}$ & $\begin{array}{l}\mathrm{ITZ} \rightarrow \mid \mathrm{AmB}+ \\
\mathrm{CSF} \rightarrow \mathrm{VRZ}+ \\
\mathrm{MCF} \rightarrow \mathrm{VRZ}+ \\
\mathrm{IAmB}\end{array}$ & No & Died \\
\hline Koncan et al. [18] & Italy & 2016 & Lung & Proven & MPAL & $\begin{array}{l}\text { Lung } \\
\text { resection }\end{array}$ & $\begin{array}{l}\text { Culture + PF-PCR } \\
+\beta D G\end{array}$ & $\mathrm{PSZ} \rightarrow \mathrm{VRZ}$ & Yes & Alive \\
\hline $\begin{array}{l}\text { Correa-Martinez et al. } \\
\text { [19] }\end{array}$ & Germany & 2017 & Skin & Proven & Nephroblastoma & Skin biopsy & Histology + culture & PSZ & Yes & Alive \\
\hline Godet et al. [20] & France & 2017 & Lung & Proven & $\mathrm{AML}$ & Lung biopsy & $D E+P F-P C R$ & $\begin{array}{l}\text { VRZ } \rightarrow \text { IAmB } \\
(\mathrm{IV}+\text { nebulized })\end{array}$ & Yes & Alive \\
\hline Jain et al. [21] & India & 2019 & Eye & Proven & $\begin{array}{l}\text { Intraocular lens } \\
\text { implantation }\end{array}$ & $\begin{array}{l}\text { Corneal } \\
\text { tissue }\end{array}$ & $\begin{array}{l}\text { DE + culture + PF- } \\
\text { PCR }\end{array}$ & $\begin{array}{l}\text { Natamycin }+ \\
\text { ITZ } \rightarrow \text { VRZ }\end{array}$ & Yes & $\begin{array}{l}\text { Alive } \\
\text { (loss of } \\
\text { the eye) }\end{array}$ \\
\hline Chauhan et al. [22] & USA & 2019 & $\begin{array}{l}\text { Lung, } \\
\text { CNS }\end{array}$ & Proven & $\mathrm{CML}$ & Autopsy & $\begin{array}{l}\text { Histology + culture } \\
+ \text { PF-PCR + } \beta D G\end{array}$ & MCF & No & Died \\
\hline Our report HA1 & France & 2019 & Lung & Probable & AML & BAL & $\begin{array}{l}D E+P F-P C R \\
+\beta D G\end{array}$ & IAmB & No & Died \\
\hline
\end{tabular}

Search for previously published cases using the terms "Hormographiella aspergillata" or "Coprinus cinereus infection" in MEDLINE database

${ }^{*} A L L$ Acute lymphoid leukemia, $A M L$ Acute myeloid leukemia, BAL Biphenotypic acute leukemia, $X$ - $A L D$ X-linked adrenoleukodystrophy, CML Chronic myeloid leukemia, MDS Myelodysplasia syndrome, MPAL Mixed phenotype acute leukemia, CNS Central nervous system, AmB Deoxycholate amphotericin B, ITZ Itraconazole, CSF Caspofungin, VRZ Voriconazole, PSZ Posaconazole, IAmB Liposomal amphotericin B, MCF Micafungin, IV Intravenous, RFLP Restriction fragment length polymorphism, DE Direct examination, PF-PCR Pan-fungal-polymerization chain reaction, $\beta D G$ 1, 3-beta-D glucan

combination with biomarkers are crucial for diagnosis. Respiratory tract colonization is probably not uncommon given that the fungus is widespread in the environment but seems to be restricted to patients with underlying respiratory diseases. $1 \mathrm{AmB}$ and voriconazole seem to be the antifungals of choice. 
Table 3 Galactomannan (GM), $\beta$-D-glucan and glucuronoxylomannan antigen assays on culture supernatant. For each strain, 5 to 10 colonies incubated at $35^{\circ} \mathrm{C}$ for 4 days on Sabouraud media were suspended in $1 \mathrm{ml}$ distilled water. After vigorous agitation, the suspensions were centrifuged for $5 \mathrm{~min}$ at 10,000 g. 1, 1:10 and 1:100 dilutions of the supernatants were then tested with Platelia ${ }^{\oplus}$ Aspergillus assay (Bio-Rad, France), Fungitell ${ }^{\circledR}$ assay (Associates of Cape Cod Inc., USA) and Biosynex ${ }^{\circledR}$ CryptoPS assay (Biosynex, France) according to the manufacturer's recommendations

\begin{tabular}{|c|c|c|c|c|}
\hline Isolate & Dilution factor & Galactomannan & $\beta$-D-glucan (pg/mL) & Glucuronoxylomannan \\
\hline \multirow[t]{3}{*}{$\mathrm{HA} 2$} & 1 & $>3,5$ & $>500$ & Negative \\
\hline & 10 & $>3,5$ & $>500$ & n.d. \\
\hline & 100 & 0,2423 & 51,048 & n.d. \\
\hline \multirow[t]{3}{*}{ HA3 } & 1 & $>3,5$ & $>500$ & Negative \\
\hline & 10 & $>3,5$ & $>500$ & n.d. \\
\hline & 100 & 0,4197 & 98,804 & n.d. \\
\hline
\end{tabular}

n.d. Not determined

\section{Abbreviations}

AML: Acute myeloid leukemia; BAL: Bronchoalveolar lavage; CLSI: Clinical and Laboratory Standards Institute; CRP: c-reactive protein; CT: Computed tomography; EORTC/MSG: European Organization for Research and Treatment of Cancer/ Mycoses Study Group; EUCAST: European Committee on Antimicrobial Susceptibility Testing; HSCT: Hematopoietic stem cell transplantation; IFI: Invasive fungal infection; ITS: Internal transcribed spacer; IAmB: Liposomal amphotericin B; MIC: Minimum inhibitory concentrations

\section{Acknowledgements}

Not applicable.

\section{Authors' contributions}

MM did the literature search and drafted the manuscript. MM, RAL, TM did the experimentations. RG, FM and PP provided guidance for drafting the manuscript. CN conceived the case report and oversaw the manuscript. All authors read and approved the final manuscript.

\section{Funding}

There was no funding for this study.

\section{Availability of data and materials}

New genome sequences obtained in this study have been deposited in GenBank under accession numbers MN841917, MN841918 and MN841919.

\section{Ethics approval and consent to participate}

This case report received approval from University Hospital of Clermontferrand Hospital Ethics and Research Committee. This document is available upon request.

\section{Consent for publication}

Written informed consent was obtained from the next-of-kin of patient HA and from patients HA2 and HA3 for publication of this case report and any accompanying images. Copies of the written consents are available for review by the Editor of this journal.

\section{Competing interests}

The authors have no conflicts of interest to declare.

\section{Author details}

${ }^{1}$ Laboratoire de Parasitologie-Mycologie, CHU Clermont-Ferrand, CHU Gabriel Montpied, 58 rue Montalembert, 3IHP, 63003 Clermont-Ferrand Cedex 1, France. ${ }^{2}$ Equipe Interactions Hôte-Parasite, Laboratoire Microorganismes : Génome et Environnement, CNRS, Université Clermont-Auvergne, Clermont-Ferrand, France. ${ }^{3}$ Laboratoire de Parasitologie-Mycologie, Département de Mycologie Médicale, Hôpitaux Universitaires de Nantes, Universités Nantes Atlantique, EA1155-IICiMed, Institut de Recherche en Santé 2, Nantes, France. ${ }^{4}$ Service d'Hématologie Clinique, CHU Clermont-Ferrand, Clermont-Ferrand, France.
Received: 31 July 2020 Accepted: 2 December 2020

Published online: 11 December 2020

\section{References}

1. Brandt ME. Filamentous Basidiomycetes in the clinical laboratory. Curr Fungal Infect Rep. 2013;7(3):219-23.

2. Speller DE, Maclver AG. Endocarditis caused by a Coprinus species: a fungus of the toadstool group. J Med Microbiol. 1971;4(3):370-4.

3. Gené J, Guillamon JM, Guarro J, Pujol I, Ulfig K. Molecular characterization, relatedness and antifungal susceptibility of the basidiomycetous Hormographiella species and Coprinus cinereus from clinical and environmental sources. Antonie Van Leeuwenhoek. 1996;70(1):49-57.

4. de Oliveira TB, Lopes VCP, Barbosa FN, Ferro M, Meirelles LA, Sette LD, et al. Fungal communities in pressmud composting harbour beneficial and detrimental fungi for human welfare. Microbiology. 2016;162(7):1147-56.

5. Nenoff $P$, Friedrich T, Schwenke H, Mierzwa M, Horn LC, Haustein UF. Rare fatal simultaneous mould infection of the lung caused by Aspergillus flavus and the basidiomycete Coprinus sp. in a leukemic patient. J Med Vet Mycol Bi-Mon Publ Int Soc Hum Anim Mycol. 1997;35(1):65-9.

6. Verweij PE, van Kasteren M, van de Nes J, de Hoog GS, de Pauw BE, Meis JF. Fatal pulmonary infection caused by the basidiomycete Hormographiella aspergillata. J Clin Microbiol. 1997;35(10):2675-8.

7. Surmont I, Van Aelst F, Verbanck J, De Hoog GS. A pulmonary infection caused by Coprinus cinereus (Hormographiella aspergillata) diagnosed after a neutropenic episode. Med Mycol. 2002;40(2):217-9.

8. Lagrou K, Massonet C, Theunissen K, Meersseman W, Lontie M, Verbeken E, et al. Fatal pulmonary infection in a leukaemic patient caused by Hormographiella aspergillata. J Med Microbiol. 2005:54(7):685-8.

9. Greer EL, Kowalski TJ, Cole ML, Miller DV, Baddour LM. Truffle's revenge: a pig-eating fungus. Cardiovasc Pathol. 2008;17(5):342-3.

10. Abuali MM, Posada R, Del Toro G, Roman E, Ramani R, Chaturvedi S, et al. Rhizomucor variabilis var. regularior and Hormographiella aspergillata infections in a leukemic bone marrow transplant recipient with refractory neutropenia. J Clin Microbiol. 2009:47(12):4176-9.

11. Conen A, Weisser M, Hohler D, Frei R, Stern M. Hormographiella aspergillata: an emerging mould in acute leukaemia patients? Clin Microbiol Infect. 2011; 17(2):273-7.

12. Suarez F, Olivier G, Garcia-Hermoso D, Randriamalala E, Ghez D, Bruneau J, et al. Breakthrough Hormographiella aspergillata infections arising in Neutropenic patients treated empirically with Caspofungin. J Clin Microbiol. 2011:49(1):461-5.

13. Pang K-AP, Godet C, Fekkar A, Scholler J, Nivoix Y, Letscher-Bru V, et al. Breakthrough invasive mould infections in patients treated with caspofungin. J Inf Secur. 2012;64(4):424-9.

14. Bojic M, Willinger B, Rath T, Tobudic S, Thalhammer F, Böhm A, et al. Fatal skin and pulmonary infection caused by Hormographiella aspergillata in a leukaemic patient: case report and literature overview. Mycoses. 2013;56(6): 687-9.

15. Corzo-León DE, Satlin MJ, Soave R, Shore TB, Schuetz AN, Jacobs SE, et al. Epidemiology and outcomes of invasive fungal infections in allogeneic haematopoietic stem cell transplant recipients in the era of antifungal 
prophylaxis: a single-Centre study with focus on emerging pathogens Mycoses. 2015;58(6):325-36.

16. Heiblig M, Bozzoli V, Saison J, Thomas X, Croze DD, Traverse-Glehen A, et al. Combined medico-surgical strategy for invasive sino-orbito-cerebral breakthrough fungal infection with Hormographiella aspergillata in an acute leukaemia patient. Mycoses. 2015;58(5):308-12.

17. Nanno S, Nakane T, Okamura H, Nishimoto M, Koh H, Nakamae H, et al. Disseminated Hormographiella aspergillata infection with involvement of the lung, brain, and small intestine following allogeneic hematopoietic stem cell transplantation: case report and literature review. Transpl Infect Dis. 2016;18(4):611-6.

18. Koncan R, Nadali G, Favuzzi V, Ligozzi M, Sorrentino A, Cascio GL. Invasive fungal infection by Hormographyella aspergillata: a tricky diagnosis triggered by (1,3)-Beta-D-Glucan assay. J Microb Biochem Technol. 2016;8(4):1-3.

19. Correa-Martinez C, Brentrup A, Hess K, Becker K, Groll AH, Schaumburg F. First description of a local Coprinopsis cinerea skin and soft tissue infection. New Microbes New Infect. 2017;21:102-4.

20. Godet C, Cateau E, Rammaert B, Grosset M, Moal GL, Béraud G, et al. Nebulized liposomal amphotericin $B$ for treatment of pulmonary infection caused by Hormographiella aspergillata: case report and literature review. Mycopathologia. 2017;182(7-8):709-13.

21. Jain N, Jinagal J, Kaur H, Ghosh A, Gupta S, Ram J, et al. Ocular infection caused by Hormographiella aspergillata: a case report and review of literature. J Mycol Médicale. 2019;29(1):71-4.

22. Chauhan A, Gruenberg J, Arbefeville S, Mettler T, Brent $\mathrm{CH}$, Ferrieri $\mathrm{P}$. Disseminated Hormographiella aspergillata infection with lung and brain involvement after Allogenic hematopoietic stem-cell transplantation in a 54year-old man. Lab Med. 2019;50:426.

23. De Pauw B, Walsh TJ, Donnelly JP, Stevens DA, Edwards JE, Calandra T, et al. Revised definitions of invasive fungal disease from the European Organization for Research and Treatment of cancer/invasive fungal infections cooperative group and the National Institute of Allergy and Infectious Diseases mycoses study group (EORTC/MSG) consensus group. Clin Infect Dis. 2008:46(12):1813-21.

24. Arendrup MC, Meletiadis J, Mouton JW, Guinea J, Cuenca-Estrella M, Lagrou $\mathrm{K}$, et al. Eucast definitive document E. DEF. 9.3.1. Method for the determination of broth dilution minimum inhibitory concentrations of antifungal agents for conidia forming Moulds. London: European Committee on Antimicrobial Susceptibility Testing; 2017.

25. Chowdhary A, Kathuria S, Agarwal K, Meis JF. Recognizing filamentous basidiomycetes as agents of human disease: a review. Med Mycol. 2014; 52(8):782-97.

26. Tone K, Umeda Y, Makimura K. Cross-reactivity in Cryptococcus antigen latex agglutination test in two commercial kits. Med Mycol. 2016;54(4):439-43.

27. lizasa T, Kamei K, Chiyo M, Suzuki M, Baba M, Toyosaki T, et al. Colonization with Schizophyllum commune of localized honeycomb lung with mucus. Respir Int Rev Thorac Dis. 2001;68(2):201-3.

28. Chowdhary A, Agarwal K, Kathuria S, Singh PK, Roy P, Gaur SN, et al. Clinical significance of filamentous basidiomycetes illustrated by isolates of the novel opportunist Ceriporia lacerata from the human respiratory tract. J Clin Microbiol févr. 2013;51(2):585-90.

29. Chowdhary A, Kathuria S, Singh PK, Agarwal K, Gaur SN, Roy P, et al. Molecular characterization and in vitro antifungal susceptibility profile of Schizophyllum commune, an emerging Basidiomycete in Bronchopulmonary mycoses. Antimicrob Agents Chemother. 2013;57(6):2845-8.

\section{Publisher's Note}

Springer Nature remains neutral with regard to jurisdictional claims in published maps and institutional affiliations.

Ready to submit your research? Choose BMC and benefit from:
- fast, convenient online submission
- thorough peer review by experienced researchers in your field
- rapid publication on acceptance
- support for research data, including large and complex data types
- gold Open Access which fosters wider collaboration and increased citations
- maximum visibility for your research: over 100M website views per year
At BMC, research is always in progress.
Learn more biomedcentral.com/submissions

